\title{
READERS WAYS BY CONNECTING OUTCOMES OF PISA AND PIAAC RESEARCH AND TODAY'S CZECH SCHOOL PRACTICE
}

\author{
Dana Vicherková1, Petra Kaduchová ${ }^{2}$, Stefan Chudy ${ }^{3}$, Imron W. Harits ${ }^{4}$ \\ ${ }^{1}$ Mgr., Palacky University in Olomouc, Czech Republic, vicherekm@c-box.cz \\ 2 Mgr., Palacky University in Olomouc, Czech Republic, kaduchova@epol.cz \\ ${ }^{3}$ Prof. Dr., Palacky University in Olomouc, Czech Republic, stefan.chudy@upol.cz \\ 4 M.A., Palacky University in Olomouc, Czech Republic, imronharits@yahoo.com
}

\begin{abstract}
The aim of this article is to think about key issues of readers 'comprehension literacy of specific category of research sample (fifteen and twenty-four) readers. To what extent is the information of both international researches implemented into reality and chosen curriculum.

In the first part of the article is introduced the basic terminology (literacy according to OECD, functional literacy and reader's literacy). It is essential to understand that it is not just about literacy skills, i.e. being able to read texts and understand them, but also the skills to find, process, and compare the information contained in the text, and reproduce text content.

In the second part the article thinks about and compares selected key data from international PISA and PIAAC research for specific category of research sample (fifteen and twenty-four years old readers). It is also worth considering whether the teaching community and the general public are aware of the need for specific measurements and the international comparison of literacy, in which the Czech Republic participates.

In the third part the article focuses on results of international research and practice in the selected curricula of pedagogic-educational institutions for the pupil population. On several examples of pupils task from Czech curriculum are explained the reading strategies. The discussed literacy strategies reflect the skill of the student to find information, process, compare, and evaluate it according to specification.
\end{abstract}

The main objective of this text is to reflect on the possibilities of linking the outputs of both readership surveys, such as functional literacy and school practice in our Czech environment.

Keywords: Literacy, reading strategy, education to reading, curricula

\section{INTRODUCTION AND BASIC TERMINOLOGY}

The education of readers is an essential educational activity to acquire functional literacy skills, which is an important input to the adoption of a number of key competences.

Reading is one of the most important educational activities for students who attend primary school (later, other educational institutions). The art of reading and understanding the text belongs among the social and cultural manifestations of advanced civilized man. Knowledge of letters is used to record information and to process 
knowledge. A related skill is to read text not only technically, but also functionally (in view of certain communication situations in daily life).

Functional literacy - skills for the implementation of various human activities necessary for life in contemporary society. It's literacy in the field of literary work, documentary, and numerical, for example, the ability not only to read, but also to understand complex texts, fill in forms, to understand graphs, tables, etc. (Prücha et al., 2009, p. 67).

Reader's literacy - complex knowledge and skills that enable an individual to deal with written texts commonly encountered in everyday life (e.g. a railway timetable, or instructions for taking medication). It is not just literacy skills, i.e. being able to read texts and understand them, but also the skills to find, process, and compare the information contained in the text, and reproduce text content, etc. (Prücha et al., 2009, p. 42).

According to the definition of literacy (according to OECD PISA), it is the skill in understanding a written text, thinking about it, and using it to achieve certain goals, to develop own abilities and knowledge, and for active integration into society (Procházková, 2002).

\section{SELECTED KEY DATA FROM INTERNATIONAL PISA AND PIAAC RESEARCH}

The organizer of the international PISA and PIAAC research is the Organisation for Economic Co-operation and Development (OECD). Both studies focus on finding the level of basic skills needed in dealing with everyday situations, and affecting the labour market.

Table 1 - Review of international comparison researches since 1995

\begin{tabular}{|l|l|r|l|}
\hline Specialization & Research & Year of data collection & Tested age category \\
\hline \multirow{3}{*}{ Reading literacy } & RLS & 1995 & 3, 8. grade of elementary school \\
\cline { 2 - 4 } & PIRLS & 2001 & 4. grade of elementary school \\
\cline { 2 - 4 } & & 2006 & without participation of CR \\
\cline { 2 - 4 } & & 2011 & 4. grade of elementary school \\
\cline { 2 - 4 } & PISA & 2000 & 15 years old pupils. 9. grade of elementary school \\
\hline Literacy of adults & PIAAC & 2009 & 16 years old pupils. 9. grade of elementary school \\
\hline
\end{tabular}

Edited according to Palečková and Tomášek (2009)

PISA (2009) focused on the target group of fifteen year old students, and PIAAC (20011/20012) on the adult population between 16-65 years old.

The aim of the PISA study was to determine whether pupils of different countries at the end of compulsory schooling acquire the knowledge and skills that are necessary for the successful involvement of young people in the real world of the new millennium (how they can use what has been learned in diverse life situations), the PIAAC research examined the level of preparedness of the adult population in modern society.

Among the surveyed PISA skills were: information gathering, processing, and evaluation of the text. PIACC monitored reading skills, information searches, the use of computers and technology, work experience, the process of initial and continuing education.

The research respected the specificities of development of literacy in each of the participating countries. Taking into account, for example, children and their maturity period of the pre-school methods of working with pupils with specific learning needs, socio-cultural differences, as well as extracurricular and lifelong learning.

In the 2009 PISA survey the Czech Republic reached $27^{\text {th }}$ place. We may see in the following charts (charts 1 and 2) an alarming fact that the number of pupils who did not reach the second level of reading literacy (see chart 3) has increased in the Czech Republic. These pupils may lack skills necessary for everyday life. 
Chart 1 - Changes in redistributionofpupils on thelevelsofreadingliteracy in PISA 2000 and 2009

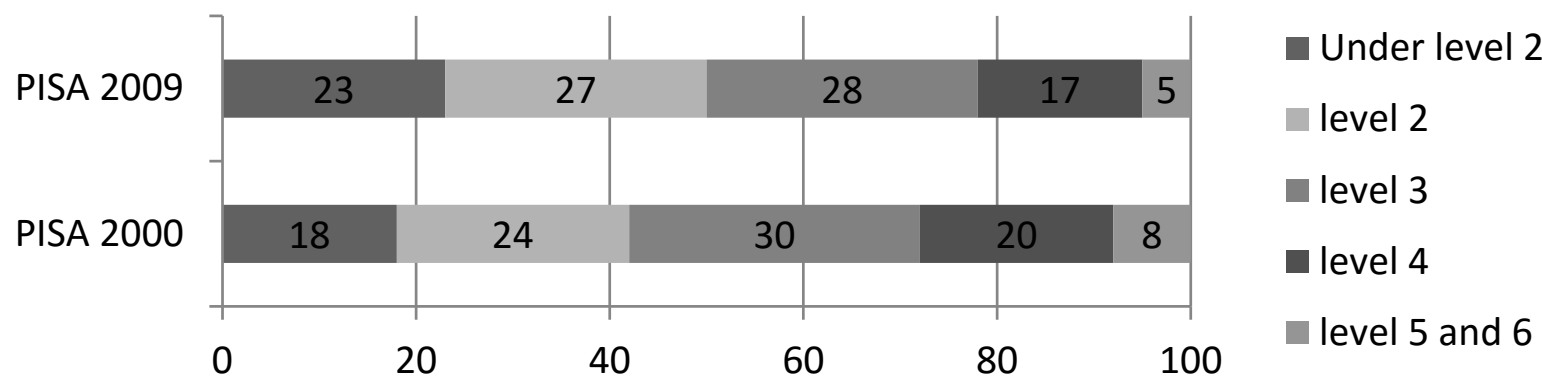

PALEČKOVÁ, J., TOMÁŠEK, V., BASL, J. (2010)1

Even though the results of Czech pupils have substantially worsened, it still ranks among countries with average differential between excellent and weak pupils.

Chart 2 -PISA 2009, percentage of students at each proficiency level on the reading literacy scale in the Czech Republic

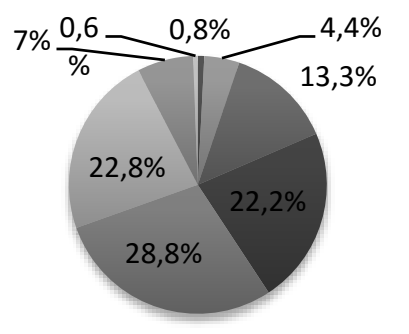

under $1 \mathrm{~b}$
$1 \mathrm{~b}$
$-1 \mathrm{a}$
-2
3
4
5

Edited according to Palečková et al. (2010, pages 46-47) and Naumann et al. (2010, page 60), selection from tables.

Chart 3 - PISA 2009, proficiency levels on the reading literacy

- Tasks require the reader to make multiple inferences, comparisons and contrasts that are both detailed and
precise. They require demonstrations of full and detailed understanding. Applying sophisticated
understanding from beyond the text is necessary.
- Tasks involve retrieving information require the reader to locate and organise several pieces of embedded
information, inferring which information in the text is relevant. Both interpretative and reflective tasks require
full detailed understanding, critical evaluation or hypothesis.
- Tasks involve retrieving information require the reader to locate and organise several pieces of embedded
information. Readers must demonstrate an accurate understanding of long and complex texts whose context
ma be unfamiliar.
- Tasks require the rader to locate, and in some cases recognise the relationship between, several pieces of
information that must meet multiple conditions. Many featurures in comparing, contrasting, categorising.
Some taskts require detailed comprehension of the text.
- Some tasks at this level require the reader to locate one or more pieces of information, which may need to be
inferred an may need to meet several conditions. Task involve comporasion and contrast based on a single
feature in text.
1a Task require the reader to locate one or more explicitly stated information, to make simple connection in the text and
common knowledge. Little, if any, competing information.
1b $\begin{aligned} & \text { - Task require the reader to locate explicitly stated information, simple text with familiar context, support to reader (pictures, } \\ & \text { symbols), minimal competing information }\end{aligned}$

Edited according to OECD PISA $2009^{2}$

${ }^{1}$ For more information see PALEČKOVÁ, J., TOMÁŠEK, V., BASL, J. (2010, s 17). Hlavnízjištěnívýzkumu PISA 2009: umíme ještě číst?

${ }^{2}$ Edited according to OECD PISA 2009 http://www.oecd.org/pisa/pisaproducts/48852548.pdf 
This contribution is dedicated to the selected category research sample of readers of 15 to 24 years of age.

\subsection{Possible Key Literacy Issues of the Czech Population}

Even though a lot of research projects deal with diverse supporting influences for the development of literacy (e.g. Hufmann, Mehlinger, and Kerivan, 2000), a key position in its development is held by the school. International studies (PISA, PIAAC) indicate the current status of literacy in comparison among member states, and it is worth considering that our level of reading strategies for fifteen year old pupils is getting worse. It is therefore important to instigate all the available measures to prevent and intervene, in order to support the development of reading skills (mainly in the processing and evaluation of information, critical thinking and interconnection processing of information in the text with their own experience gained in everyday life).

To understand the European trends in attitudes to reading and reading skills, it is necessary to analyse existing educational curricula, which define the boundaries and possible methods of reading literacy development. The possibility of comparison with other countries is an inspiration for the possible modification of teacher training, including support for the development of reading.

Among other factors affecting literacy, own didactic work of teachers (choice of methods), course organization, the number of pupils, amenities classrooms, school libraries, and other educational centers must be included. School experience shows weak motivation and the unwillingness of many teachers use appropriate methodology (methods of critical thinking, teachers working with art books, literature for youth, etc.). From interviews with teachers of different kinds of schools that have taken place in the context of our survey, we can see that across all stages, teaching the Czech language and literature only work with excerpts from artistic literature in papers prevails. It also showed that the development of a comprehensive approach to reading is mostly applied only in the first grade of primary school (reading skills are dealt with by teachers not only in teaching the mother tongue, but also in other subjects). The situation is different for the second grade of primary schools, where we find a comprehensive approach to reading virtually missing (reading skills deal only with learning the Czech language and literature, and sometimes foreign languages). In the third grade of education, the introduction of the state graduation exam returns to Czech language and literature, using the book as a whole (not just extracts from the texts).

Although for mutual understanding of content being communicated, communication between people is important; our findings do not reflect this fact, because schools do not respect the requirements for mastering the basic rules of language and communication training, stylistic and literary education, as applied in everyday life.

The question is to what extent our contemporary curriculum characterizes and develops literacy skills in all areas of our education. It is also worth considering whether the teaching community and the general public are aware of the need for specific measurements and the international comparison of literacy, in which the Czech Republic participates.

\section{RESULTS OF INTERNATIONAL RESEARCH AND PRACTICE IN THE SELECTED CURRICULA OF PEDAGOGIC-EDUCATIONAL INSTITUTIONS FOR THE PUPIL POPULATION}

Human personality develops even at a preschool age, when developing need and motivation for selfknowledge (i.e. different literacy, including reading literacy, which is enshrined in the current pre-school, and later school, curriculum). Curricular document FEP 2004 does not contain the characteristics leading to reading skills. It is up to the teachers of preschools how their educational and training activities are used to develop literacy skills, and they often substitute their own expert ideas for the gaps in the existing general educational programme for preschool education. According to the survey (Kropáčková, Wildová, Kucharská, 2014) some hope of change (adding measures to promote and develop pre-reading skills and their methodology) in the basic preschool curriculum was brought by the thematic report published by the CSI to support the development of literacy in preschool and primary education (2012). It can be stated that the systematic teaching of reading and writing is performed from compulsory school attendance.

In economically and socially developed countries, they are laying the foundation for lifelong learning as early as in pre-school education, which reveals the results of the PIRLS and PISA investigations. Here it confirms that pupils attending nursery school and kindergarten perform significantly better, and often reach a higher level of education. 
In 2001 the so-called National Programme for the Development of Education - White Paper, which forms a coherent concept of education development in the Czech Republic for the next period of 5-10 years, was published.

The Framework Educational Programme for Basic Education (FEP) has an educational portion divided into nine educational areas, which are composed of one educational field or interlinked educational fields (the titles subjects). In 2007, there was a realization of FEP in all elementary schools in the Czech Republic in the form of school educational programs (SEP) of individual schools (under elaboration on the specific conditions of their school environments).

According to Svrčková (2011) and Kropáčová (2006), the current form of FEP insufficiently appeals to the development of literacy (hereinafter LS) of students (in importance for success in everyday life).

Literacy skills, or their components, do not figure as an important goal at any level in the FEP. The FEP is not a required systematic development of literacy skills of each pupil and literacy as such, then it is not integrated at the level of general education, and binding targets is also built next to the key competences. Expected outputs of individual disciplines require mastery of some of the components of LS mostly only in fields that are traditionally perceived as appropriate, and where the reader is reading, and readership is largely a self-content industry (language and communication training, literature). Even here, LS is not systematically covered in the modern meaning. Other courses and cross-cutting themes in the contemporary conception of the curriculum contribute to the development of LS sporadically, although their role can and should be much more substantial. (Švrčková, 2011, p. 26)

Since 1.9.2013, the effective major curricular document Framework Educational Programme for basic education (for the full text of the modified FEP), whose Annex 1 is the document Standards for basic education. We will focus on text analysis targeted for pupils of 2nd stage primary school (9th grade).

An urgent problem of today's educational curriculum documents is whether it puts sufficient emphasis on explaining the needs of a pupil in education (respect for individual differences in abilities, skills, knowledge of pupils). The valid revision of FEP has been some changes in the concept of education, but in advisory didactic teaching of the mother tongue, it does not separate (specific) emphasis on developing reading strategies (only as part of communicative competences). Standards for Basic Education of the Czech language and literature prepared pursuant to the modified FEP, effective from 1. 9. 2013, include the ten expected results in the thematic area called 1. Communication and Education Essay, eight expected outcomes in the area named 2. Language Education and nine expected outcomes in the area named 3. Literary Education.

From this document (Standards for ČJL ZV), it is not entirely clear how exemplary the role of developing specific reading strategies and skills are that international surveys of literacy focus on. Thorough study and analysis of standardized tasks, training facilities can specify reading skills, as targeted by PISA and PIAAC. For example, skills focused on information gathering, processing, and evaluating information.

\section{Example 1}

Reading, comprehension, and readership strategies dedicated to the first thematic area of Communication and Composition, and these expected outcomes FEP: ČJL-9-1-01 (e.g. in reading the text, the student has to distinguish facts from opinions and assessments, collate and verify facts through questions with other available sources of information). The discussed literacy strategy reflects the skill of the student to find information, process, compare and evaluate it according to specification.

\section{Example 2}

The expected output of FEP ČJL-9-1-06 (currently included in the above document of 1.9.2013) seeks to distinguish prepared and impromptu speech communication. It emphasizes the diversity of verbal, nonverbal, and paralinguistic means of language. There it obviously applies to reading education, for example, selecting an appropriate reading tempo, phrasing, intonation according to the kinds of sentences under the rules of pronunciation. The benefit is an appeal to productive short key information, distinguishing speech in private, and in public. Illustrative work leads to students being able to talk about a topic they understand (e.g. by providing the information in speech). The acquired skills can be applied in working with texts (e.g. what a given character says and why). There are noticeable signs of working with information, analysis, and evaluation of the text. 


\section{Example 3}

The expected output of FEP ČJL-9-3-03 is directed to the expression (sharing) of personal impressions from reading, and others. It is the expression of views on the work of art (an appeal to the right argument, stating both positive and negative opinions). An illustrative role belongs among the readership strategies in evaluating text.

In conclusion we can say that in the analyzed curriculum document (text analysis is based on tested methodology to be used in an international survey of reading literacy of fifteen year old pupils) Standards for Basic Education of the Czech language and literature processed according to the modified FEP (with specifications for the 2nd stage of primary school, 9th grade) are processed selected current output from the field of literacy training reading strategies consistent with tested skills of reading literacy and reading performance at international measurements (PISA 2009)were processed, as witnessed by the above analysis of the document. But we cannot expect a significant improvement in Czech pupils in reading, since some lack of unified specialized terminology of LS (terminology) in all curricula (FEP Standards for Basic Education of the Czech language and literature, (with specifications for the 2nd stage of primary school, 9th grade) is missing.

Also obvious is the absence of systematic development of each pupil's LS. Given that the LS is not integrated at the level of general education, and mandatory targets are not built next to key competences, we don't think that we can expect significant improvement in Czech students in reading in other international surveys in the future. Of course, in this troubled area being examined, LS plays a role not only for students, but also for their teachers and learning materials (ČJL textbooks).

It is certainly a question of the extent which ČJL textbooks meet (for students of 9th grade), based on the requirements of the mandatory curricula, and to what extent teachers (Czech language) of fifteen year old students are interested in the results (outcomes) of international LS research. Whether teachers have an interest, motivation, time, and space for further education in the monitored problematic plane.

\subsection{Results of International Research and Practice in the Selected Curricula of Educational Institutions of the Adult Population}

Another part of this paper focuses on the adult population. In the youngest age groups of the adult population (16-24 years), research showed worse results, just like in other developed countries. Despite this deterioration, however, it is the youngest group who were evaluated at least as average.

The group that achieved the worst results among the population was 35-54 years. Apparently, here we see the results of a hectic period, heavy workload, parenting, and a lack of time for hobbies and personal skills development.

On the contrary, as for tendencies for improvement, we can talk about the older adult population of between 55-65 years, presumably because they are not professionally active, and therefore have more time to devote to educational activities that promote personality development, and improve the quality of life.

For university educated individuals, results in reading literacy have worsened since 1998, probably in the context of increasing access to higher studies, the skills of Czech university students still remain above average in international comparisons. The research brings indisputable evidence that skills increase with increasing education.

In our selected adult population, i.e. 16-24 years, we focus on analyzing the curricula of secondary education (the catalogue of testing requirements for school-leaving examinations in the Czech language and in literature).

For secondary school pupils, teachers, and the educational community (as well as the lay public), it is important to monitor developments and the educational concept of a unified state graduation exam in Czech language and literature.

On 30. 4. 2013, the Ministry published (in accordance with Act No. 561/2004 Coll., On preschool, primary, secondary, higher professional, and other education - the Education Act, as amended by subsequent regulatory documents), catalogues tests required for school-leaving examinations in foreign languages, mathematics, and Czech language and literature. With the above requirements, tests and sub-tests of schoolleaving examinations held after 1.1.2015 will be developed.

Catalogues are mandatory educational documents that are based on the framework of educational programmes for secondary schools and general educational programmes for the fields of secondary vocational 
education with school leaving exams (effective from 2007), and valid teaching documents for secondary vocational schools. In the preparatory process, catalogues were also based on the Standard of Secondary Vocational Education, issued by VúOŠ Prague (with effect from 1.1.1998).

The publication of catalogues of requirements for 2015 (the revision of previously existing catalogues) has not fundamentally altered the structure and scope of school leaving examinations in Czech language and literature, but thanks to the professional pedagogic and public discussion, it has stabilized the structure of the text, with the option to maintain comparability between test tasks and assignments. Parts of the individual catalogues are examples of test tasks and examples of written work assignments, as well as a worksheet for the oral exam.

We consider the openness and accessibility of information output on the current curricula on the CERMAT website (www.Novamaturita.cz)a positive direction in education. On this website, there is valid information on the organization and preparation for the school leaving examination in the current period (for pupils, teachers, and the general public). The graduation Bulletin is published regularly in advance, with a summary of key information on selected problematic phenomena. The practice, repetition, and examining pupils' knowledge and skills can be used in the archives of graduation assignments (tests, essays, as well as worksheets, sample tasks with solutions) from previous years of state school leaving exams.

Research has shown that today's schools are not sufficiently harnessing their full potential for the development of literacy, for example, because questionnaires for teachers and students, as well as interviews, revealed insufficient teacher support in active and productive work with the text. Reproduction of the text is predominant. The aforementioned outlets also confirmed the PIRLS test results, which showed that teachers mainly used reading material in a uniform manner, regardless of the reading level of students, reading comprehension is only checked verbally, by reproduction, or identifying the main ideas, and less frequently compared to the experience of the student or other texts, not developing skills in anticipation and generalization (Najvarová 2008, p. 20).

In reading literacy, from 2000 to 2009, the results of primary school pupils and students in school leaving and non-school leaving exam programs of secondary vocational schools significantly worsened. This increased the gap between the results of these pupils and pupils of grammar schools, whose results are virtually unchanged. (Palečková, J., Tomášek, V., Basl, J., 2010, p. 35)

It can be stated that education towards reading is deliberately conceived conceptually. The level of pupils' reading strategies at the end of secondary studies is evaluated by the didactic text form (since the school year 2014/2015 it has contained a didactic test with open and closed tasks), and oral examinations (artistic and non-artistic analysis of the text).

\section{CONCLUSION}

It is worth considering that the Czech pupils in reading literacy tests only achieve average results. Their results are comparable to, e.g. the results of Austrian and Slovakian pupils; but the youngest population of students from neighboring Poland, Germany, and also pupils from Hungary, fared better. The Czech Republic is also among the top five OECD countries which, since 2000, has had a significant deterioration in results (Australia, Sweden, Austria, and Ireland). The failure of Czech pupils in reading literacy is a problem concerning fact processing, comparison, analysis, interpretation, and evaluation.

The PIAAC final results confirm the hypothesis of declining education of the Czech adult population. The Czech Republic has achieved average results in reading, because reading proficiency in Czech adults can be compared with the level of literacy in 1998.

Many reading studies indicate the necessity of taking a complex look at developing reading strategies - across all stages of human development, from childhood, through youth, and into adulthood. Based on international research, we see that immature literacy leads to study problems, and then to the difficulties associated with finding work (we are talking then about functional illiteracy). With a lower level of education attainment, difficulties in social application are closely related.

Education dedicated to reading occurs in varying degrees at all grades of schools, but not to the same degree. The teacher's personality and specific didactic work are always important, which lead to education in reading, and respecting the existing curriculum, and possibly the complementary absence of the above-mentioned problem areas. 
In accordance with principles of international and national curricular policy (The White book, 2001) and act $561 / 2004$ and RVP ZV (2013) are in all phases of education stressed out key competences, their interconnectedness with educational content and application of knowledge in real life. We consider interconnection of PISA and PIAAC research challenge for further education of people. Lifelong education is becoming a dynamic developing human need.

\section{AKNOWLEDGEMENTS}

IGA_PdF_2015_022 Thephenomena of relationships between education and thinking in constructivism education.

IGA_PdF_2015_026 Analysing the reflexion of specific pedagogical disciplines in the process of constituting pedagogical knowledge in students of PdF UP in Olomouc.

Internal grant of PDF UP: From subjective implicit theories of education to teaching knowledge. The process of constitution of a cognitive framework sciences education in the national and international context.

\section{REFERENCE LIST}

Huffman, L., Mehlinger, S., Kerivan, A. (2000). Risk factors for academic and behavioral problems at the beginning of school. In off to a good start. Research on the risk factors for early school problems and selected policies affecting children's social and emotional development and their readiness for school. Chapel Hill: University of North Carolina.

Kropáčková, J. (2006). Výuka žáka sodlišným mateřským jazykem.Olomouc: Univerzita Palackého v Olomouci.

Kropáčková, J., Wildová, R., Kucharská, A. (2014).Pojetí a rozvoj čtenářské pregramotnosti v předškolním období. Pedagogická orientace, 24 (4), 488-509.

Ústav pro informace ve vzdělávání. (1999). Měření vědomostí a dovedností: nova koncepce hodnocení žáků. Praha: Ústav pro informace ve vzdělávání. Dostupné z: http://www.csicr.cz/getattachment/cz/Onas/Mezinarodni-setreni-archiv/PISA/PISA-2000/Mereni-vedomosti-a-dovednosti-publikace.pdf

MŠMT.(2013). Zveřejnění prvních výsledků výzkumu OECD PIAAC. Dostupné z: http://www.msmt.cz/ministerstvo/novinar/zverejneni-prvnich-vysledku-vyzkumu-oecd-piaac

MŠMT. (2013). Upravený rámcový vzdělávací program pro základní vzdělávání platný od 1.9.2013. Praha: MŠMT. Dostupné z http://www.msmt.cz/vzdelavani/upraveny-ramcovy-vzdelavaci-program-prozakladni-vzdelavani

MŠMT. (2013). Standardy pro základní vzdělávání. Praha: MŠMT. Dostupné z http://clanky.rvp.cz/clanek/c/Z/17383/STANDARDY-VZDELAVACICH-OBORU-ZAKLADNIHOVZDELAVANI---VEREJNE-PRIPOMINKOVE-RIZENI.html/

Najvarová, V. (2008).Čtenářská gramotnost žáků 1.stupně ZŠ. Pedagogická orientace,18 (1), 7-21.

Palečková, J., Tomášek, V., Basl, J. (2010). Hlavní zjištění výzkumu PISA 2009: umíme ještě číst? Praha: Ústav pro informace ve vzdělávání.

Procházková, I. (2002). Sympozium PISA v Berlíně - zpráva ze zahraniční služební cesty. Praha: Univerzita Karlova.

Průcha, J. (2009). Pedagogická encyklopedie. Praha: Portál.

Švrčková, M. (2011). Kvalita počáteční čtenářské gramotnosti.Výzkumná analýza a popis soudobého stavu.Ostrava: Ostravská univerzita v Ostravě. 